\title{
NATHALIE SARRAUTE, O NOUVEAU ROMAN E A LIÇÃO DO ETERNO RECOMEÇO
}

\author{
Maria Luiza Berwanger da Silva
}

\begin{abstract}
RESUMO: Cette étude se destine a ponctuer quelques axes définitifs pour la production littéraire de Nathalie Sarraute comme écrantillon exemplaire du Nouveau Roman, motivant l'apport de cette école pour la théorie et la critiquede l'écriture dans la modernité. À la finde l'étude, un certain dialogue est ébauché entre Nathalie Sarraute et le poète brésilien João Cabral de Melo Neto concernant la conscience de la productiveté textuellle, nucléaire pour la révision du canon brésilien aussi bien que pour la Littérature Française. Il faut, donc, souligner le ton révisioniste à peine commencé dans cette briève étude.
\end{abstract}

PALAVRAS-CHAVE: Nathalie Sarraute, Nouveau Roman, Literatura Francesa, João Cabral de Melo Neto, Literatura Brasileira.

Memória da leitura ou leitura da memória?

Permanece imemorial aquela imagem primeira, aquela paisagem singular e inapagável da recepção da Literatura Francesa no Curso de Letras da UFRGS, onde ingressavam entusiasmados jovens trazendo, do então Curso Clássico, a convicção do que pensavam constituir, na época (precisamente em 1968, próximo a maio), a representação canônica da produção literária pontuada pelo belo artístico. Bela alienação e bela lembrança que o impacto das aulas sobre o Nouveau Roman provocava nos "sólidos" conhecimentos sobre o romance realista francês e o brasileiro. A perplexidade emergia, talvez, do próprio reexame crítico insinuado pela dissimulação (voluntária) de Capitu, personagem machadiana e pelo Ateneu de Raul Pompéia, entre tantos outros. A sensibilidade, formada ou deformada pelos manuais de história literária, nos chegara, não sem um mínimo de suspeita, de que o texto continuava a produzir-se além da página e que o inclassificável ou o irrepresentável não pareciam carentes de significação poética.

Rememorar, hoje, a presença da escritora francesa Nathalie Sarraute, uma das figuras mais representativas do Nouveau Roman, equivale a deparar-se com esse arquivo da memória, acionado não apenas para recompor uma época, um fato e um lugar: o arquivo seduz quando revisa imagens que ainda hoje se comprazem na sistematização do fato teórico, a do gênero romanesco especialmente, já desde Diderot, e que o Nouveau Roman incorpora de modo exemplar. Nas palavras de A Era da Suspeita (L'Ère du Soupçon - 1956) de Nathalie Sarraute:

"Começa-se agora a compreender que não se deve confundir, sob a mesma etiqueta, a velha análise dos sentimentos [...] com o movimento das forças psíquicas desconhecidas da qual não se priva nenhum romance moderno [...] Hoje, mesmo os romancistas tradicionais, aqueles que se parecem contentar com as formas mais usadas e desgastadas do diálogo, começam a confessar que esse lhes 'causa problemas"( SARRAUTE, 1956. p.11-12.).

A leitura de Tropismos (1939), romance inaugural, seguida de Retrato de um Desconhecido (1948) ou mesmo de obras mais recentes como é o caso de L'Usage de la Parole (1980) e Enfance (1983), não esbarram, contudo, no mero vício teórico. Se, de um lado, o contato com tal produção

· Maria Luiza Berwanger da Silva é professora no Instituto de Letras da UFRGS 
atenua a "resistência à teoria", reconciliando o leitor com a prática de leitura, de outro permite-lhe visitar os bastidores da fabricação que busca incorporar o "prazer do texto" ao próprio percurso da visita. Por isso, ainda que Roland Barthes tenha deixado transparecer certas críticas à "École du Regard", imagem representativa do Nouveau Roman, principalmente em textos de Ensaios Críticos (Essais Critiques, Paris: Seuil, 1964), é com base nessas insinuações e desse diálogo com a tradição romanesca que captará as bases para a sistematização do "efeito do real", segundo o qual a literatura não reproduz, isto é, não copia totalmente o real sem transformá-lo ou, como o diz, sem "produzi-lo", reinventando-o. No rastro de Barthes teóricos franceses como Pierre Brunel em Transparences du Roman (Le Romancier et ses Doubles au XX ème siècle - 1997), bem como Jean Bessière em Problématique des Genres, Problèmes du Roman (1999), sugerem a contribuição residual do Nouveau Roman. Aportam no desdobramento do olhar que se volta, paralelamente, a múltiplos lugares.

Nathalie Sarraute agrega ao olhar prousteano do "caleidoscópio da obscuridade" não apenas o reflexo da visão disseminada; extrai da efervescência interior a emergência do novo e do indizível, como solo da experiência sensível, produzida entre o uno e o múltiplo. A passagem de Sarraute, nesse momento finissecular (diverso e global), relembra as próprias marcas que a cultura francesa imprimiu na história da mentalidade brasileira, possibilitando recartografar o nacional literário e artístico. (Refiro-me à lucidez do artigo "A França, o Óbvio e o Chiclete”, de Guilhermino César. Suplemento do Correio do Povo de 29/9/73). Nessa autora, a preocupação de recuperar o sentimento humano, oculto sob cores, perfumes e formas dos objetos agrega, à recuperação prousteana do tempo, a consciência do movimento que conforma a subjetividade múltipla e fragmentada. Desse modo, a presença marcante de Proust em Sarraute parece auxiliá-la duplamente: se, pela consciência da mudança, concede-lhe a representação do irrepresentável, pela ilusão da plenitude, viabiliza para o leitor o registro do olhar, cuja vitalidade deixa-se compor do próprio ato da leitura, equivalendo a dizer que: o texto de Sarraute sistematiza, a seu modo, um certo projeto de estética da recepção com base na "suspeita" (soupçon), fertilizadora dos valores romanescos. Subjaz, pois, ao jogo que estabelece com seus contemporâneos (Alain Robbe-Grillet, Michel Butor e Claude Simon), o desejo de reordenação do real com vistas a consolidar a relação (saudável) da Arte com a Vida. Transparece, nos romances de Nathalie Sarraute, esse efeito do provisório e do inesgotável que gera o desafio da recomposição do literário como recomposição existencial, da reconfortante sensação do imaginário que renasce infinitamente do desejo de ser o Outro em sendo o Mesmo. Portanto, o fato de legar à tradição literária a consciência da transgressão e da passagem antecipa a dimensão da identidade compartilhada: a saturação do globalizado, a desfaz a certeza de que a impregnação do Alheio não retrai a singularidade do Próprio, resgatado pelo constante apelo a imagens imemoriais. Retornar, pois, ao impacto inicial acionado pela lembrança dos idos de 68 e da incomensurável projeção sobre a formação de tantos leitores brasileiros, de tantos percursos literários (ou não), reverte aquela prática de leitura inaugural e desconfortante. A freqüente visitação de textos que imprimiam uma respiração nova na produção literária, a qual passava a questionar pressupostos teóricos estabelecidos, tais como o gênero, hoje híbrido, o sujeito neutro, mas múltiplo, e o lugar exótico e universal, fazem-se acréscimos modeladores da recepção crítica atual.

A França perde Nathalie Sarraute e o Brasil, há poucos dias, foi privado do suave convívio com o poeta João Cabral de Melo Neto. Não perdem, entretanto, os dois países, a consolidação da leitura como projeto de revisão do canônico e do definitivo. Instala-se a "era da suspeita" (l'ère du soupçon). Suspira-se insinuação e toda insinuação é produtiva quando reaviva, no resgate de uma memória, aquele brilho do olhar que apostou desde sempre na alegria, na continuidade e no encantamento. A melodia da voz de João Cabral de Melo Neto em Debruçado sobre os Cadernos de Paul Valéry ("Quem que poderia a coragem de viver em frente da imagem / do que faz, enquanto se faz, antes da forma, que a refaz? / Assistir nosso pensamento a nossos olhos se fazendo, / Só sei de alguém que tenha tido a coragem de se ter visto ... e de tudo o que pode a linguagem: Valéry - que em sua obra, à margem, revela os tortuosos caminhos ... que vão dar no perfeito cristal...”)( MELO 
NETO, s.d., p.559), entrelaça-se a da figura sisuda, mas sensível, de Nathalie Sarraute em recente entrevista, onde reitera a lição cabralina do eterno recomeço:

"Quando o autor trabalha e retrabalha a frase e ela se torna bela demais, perde o contato com a sensação que lhe deu origem. A frase se torna morta, responde a um cânone de beleza. É perigoso. É preciso então recomeçar tudo de novo, voltar à sensação, para que a frase viva por meio da escrita"( SARRAUTE, 1996, p.168).

Memória da leitura e leitura da memória.

\section{BIBLIOGRAFIA}

MELO NETO, João Cabral de. Obra completa. Rio de Janeiro: Aguilar, s.d.

SARRAUTE, Nathalie. L'ère $d u$ soupçon. Paris: Gallimard, 1956. (O fragmento citado foi traduzido

pela autora deste artigo.)

SARRAUTE, Nathalie. In: MILAN, Betty. A força da palavra. Rio de Janeiro: Record, 1996. 